Aliyeva T.I.

DOI: 10.25108/2304-1730-1749.iolr.2017.52.6-20

\title{
On some criteria of admissibility of tactical techniques of witnesses' interrogation
}

\begin{abstract}
Ethic and psychological basis of an interrogation's production should be directed not only to cognition of the objective regularities in the aspect of moral and scientific issues of criminalistical tactics but also they are eligible to assist of application only well-grounded research methods. It seems that it is completely inadmissible hypothetic and probabilistic subjective approaches in determination of development's directions of criminalistical tactics interrogation.
\end{abstract}

Keywords: tactical technique; admissibility; interrogation of witness; criminalistics; recommendation.

Scientific validity, compliance to the requirements of law and ethics, and also expediency and recommendatory nature are considered to be as the necessary signs of criminalistical tactical techniques. Wherein, scientific validity, ethicality and lawfulness are the criteria of admissibility of tactical techniques of witnesses' interrogation.

Incompliance of recommendation to one of the criteria of admissibility makes impossible its application in investigative and judicial practice, and also does not allow naming it as criminalistical tactical technique. An investigator's behaviour, which has no reasonable nature or follows to provisions of non-recommended issue, but at the same time, it corresponds to law and ethics' requirements, in our standpoint, and nevertheless, it is quite admissible.

\footnotetext{
- Aliyeva Tarana Ilyas qyzy - a dissertator of the Institute for Philosophy, Sociology and Law of the NAS of Azerbaijan Republic, a member of the IOLR (Azerbaijan). E-mail: mopi_sid@yahoo.com
} 
Thus, expediency and recommendatory nature are the necessary features of the tactical technique, but they are not the criteria of admissibility.

Etymologically, the term "criterion" is understood as "a sign, on base of which is conducted assessment, definition, classification of something, a yardstick" [3, p. 307]. Criterion of admissibility serves a yardstick, which not only determines an essential side of scientific category of tactical technique, but also resolves the issue of possibility to apply the recommendation suggested.

Under criterion of admissibility of tactical technique in criminalistics should be understood an essential sign of the latter, incompliance of which makes impossible to apply a recommendation suggested. Therefore contradiction of the one of criteria of admissibility relates the recommendation suggested to a number of illegal and inadmissible methods.

In literature apart from named criteria of admissibility other requirements are also related to them. So, to the criteria of admissibility of tactical technique N.I. Porubov relates the expediency of using, effectiveness and economic feasibility, and also accessibility of the technique [4, p. 96]. This standpoint seems to be arguable as expediency is rather an assignment of the tactical technique than a criterion of admissibility. Expediency is a necessary property of the tactical technique, which reflects a direction of its usage. However a person, who conducts an investigation, may in terms of the tactical risk apply in expedient tactical technique, which unlikely might be called in this situation as inadmissible. It seems that effectiveness and economy nature should be absorbed with expediency's property.

As it seems, a criterion of accessibility may not have an independence nature as it enters by its content either a criterion of scientific validity or in lawfulness' requirement.

Term "principle of accessibility" applied by N.I. Porubov, does not contradict a category of "criterion" however the first has more common character. 
Etymologically the both a principle and criterion may act as evaluative factors, on base of which an admissibility is determined.

Thus, tactical techniques of witnesses' interrogation should be corresponded to the criteria of scientific validity, legality and ethicality. Therefore, it seems arguable a distinguishing of the criteria, which have no an independence character or are substantive sign of tactical technique, which does not solve an issue on admissibility of this recommendation.

Without belittling of requirements of scientific validity and ethicality, A.P. Ratinov has rightly noted "absoluteness of the highest procedural and legal criterion" [5, p. 66]. Such understanding of priority of lawfulness is also reasonably in modern conditions of law-based state's construction.

Meanwhile, there are theoretical concepts in literature, which in our standpoint, do not draw a proper attention to legality's requirements of tactical techniques. Particular, N.A. Selivanov sees in the requirements of legality and ethicality something taken for granted, therefore, in his opinion, these signs should not be included in definition of tactical technique [7, p. 83]. It is difficult to agree with this position as any definition of scientific category should be characterized with completeness, and such understanding ignores of sufficient signs.

Exception of the criteria of admissibility from definition of tactical technique will be meant unfounded extension of this concept, and illegal and non-ethic methods of impact will be corresponded to this term. In addition, criminalistics has independent subject of study, and presence of legality principle in criminal process is not an argument in favour of the fact that to exclude criterion of admissibility from the list of essential signs of "tactical technique" concept. Somewhat later N.A. Selivanov rightly wrote that those techniques should be considered as admissible, which meet requirements of scientific viability and do not contradict the norms and principles contained in law and by-laws [6, p. 24]. 
These criteria are seemed universal and comprehensive for any tactical techniques, and not only for interrogation of witnesses. In law-based state to principle of legality should be followed not only lawmaking activity of state (hierarchy of legislative acts, supremacy of constitutional norms, certain order of change and repeal of criminal procedural norms and others), but also practical activity on investigation of criminal cases.

Criterion of legality of tactical techniques is narrower concept than principle of lawfulness. The principle of lawfulness is touched not only application of science's recommendation, but any behaviour of inquiry officer, investigator, prosecutor, judge in process of crimes' investigation. In work of investigator is often undertaken the actions, which are not based on data any sciences, but they should be corresponded to law. Thus, principle of lawfulness is comprehensive concept while a criterion of compliance to law of tactical recommendations is touched only the tactical techniques and their combinations.

Contradistinctions of criteria of legality and ethicality are met in literature. So, N.L. Granat notes: "In connection with denying of formal lawfulness the tactical technique, which does not correspond to category of fairness that is provided by non-legal law or non-contradicting to such law, should be considered as inadmissible. Appeared necessity of moral evaluation of "means" used creates additional requirements to a level of investigator's professionalism" [2, p. 22]. In this case through denying of formal lawfulness is declared voluntary beginning in investigator's activity that, in our standpoint, will inevitably lead to accusatory manner.

Investigatory and judicial practice closely tied to lawmaking as criminalistical recommendations are often become the norms of criminal procedure law. This process is quite natural ad justified since it directed to assistance of more complete, comprehensive and objective cognition and establishment of the true on every criminal case investigated. 
Criterion of legality of tactical techniques with its requirements permeates tactics of production all investigative and judicial actions. This circumstance does not impede to develop a content of this criterion concerning a tactics of separate procedural actions. Professor A.N. Vasiliev fairly included in content of legality of the tactical techniques of interrogation a focus on obtaining truthful and reliable testimonies, strict observance of procedural rules, and prevention of violations of prohibitions provided by law and their compliance to the norms of law [2, p. 16].

Observance of these requirements is obligatory not only for practitioners but also for scientists-criminalists suggesting new and improving existed tactical methods of interrogation. Any misunderstanding of significance of this criterion of admissibility can lead to irreparable consequences for the both the criminalistics and practice of investigation of criminal offences. Thus, criterion of lawfulness determines also direction of criminalists' research, reflecting substantive side of any tactical method of questioning.

One of the most important criteria of admissibility of tactical methods of interrogation should be recognized its ethicality. Ethics is a science on moral like a form of social conscience, determining the requirements brought to a member of this society. Ethicality requirement inextricably linked to criteria of lawfulness and scientific validity since it substantially supplements the latter. Conformity of recommendation to moral requirements is necessary sign of any criminalistical tactical technique. L.E. Arotsker was completely right, when noted that "an opportunity of practical use of that or other method depends on its conformity to moral requirements of investigative ethics" [1, p. 53-54].

Ethics is a separate science, and universality its requirements determined an independence of criterion of conformity to moral instructions of criminalistical recommendations.

However, we should forget that all criteria of admissibility are in the closest interconnection. These ties might be subdivided into the two categories: defining 
and one-ordered. So, academic research of psychology and physiology of human body determine consequences, which are caused with certain methods of psychological impact in course of production of investigative actions. Influence of these consequences on human health allows judging about their conformity or inconformity to ethic instructions. Here data, which received during psychophysiological research, are the defining in respect to ethicality of application of the methods mentioned. One-ordered ties are characterized with simultaneous and equal compliance or incompliance to various criteria of admissibility of the methods applying during collection, assessment, examination and usage of criminalistically significant information.

We should keep in mind that scientific validity of recommendations in frames of one science not always means its unconditional applicability in criminalistics. So, techniques of military tactics of combat conducting cannot be mechanically applied in criminalistical tactics of questioning. Thus, criteria of admissibility of tactical techniques are methodological prerequisite to develop and improve criminalistical recommendations.

\section{References}

1. Arotsker L.E. O sootnoshenii protsesual'nykh i eticheskikh nachal v sledsnvennykh deystviyakh // 50 let sovetskoy prokurature i problem sovershenstvovaniya predvaritel'nogo sledstviya [On relationship of procedural, tactical and ethic beginnings in investigative actions // 50 years of soviet prosecutor's office and problems of improving preliminary investigation]. Ed. by V.S. Afanasiev, L.A. Andreeva and others. Leningrad, 1972, pp. 52-59.

2. Granat N.L. Pravovye i nravstvenno-psikhologicheskie osnovy obespecheniya zakonnosti na predvaritel'nom sledstvii [Legal and moral- 
psychological basis of ensuring of legality on preliminary investigation]. Aftoref. dis... doct. yurid. nauk. [Abstract of Diss. of Doct. of Law]. Moscow, 1992, 46 p.

3. Ozhegov S.I., Shvedova N.Yu. Tolkovyi slovar' russkogo yazyka [Explanatory dictionary of Russian language]. Moscow, 1999, 944 p.

4. Porubov N.I. Nauchnye osnovy doprosa na predvaritel'nom sledstvii [Scientific basis of interrogation on preliminary investigation]. Minsk, 1978, $176 \mathrm{p}$.

5. Ratinov A.R., Efimova N.I. Psikhologiya doprosa obvinyaemogo. Dlya sluzhebnogo pol'zovaniya [Psychology of interrogation of accused person. For official use]. Moscow, 1998, 106 p.

6. Selivanov N.A. Kriterii dopustimosti primeneniya takticheskikh priyomov pri rassledovanii [Criteria admissibility of application of tactical techniques at investistigation]. Zakonnost' [Legality], 1994, no. 4, pp. 22-26.

7. Selivanov N.A. Sovetskaya kriminalistika: sistema ponyatiyi [Soviet criminalistics: system of notions]. Moscow, 1982, 152 p. 